CESIS Electronic Working Paper Series

Paper No. 371

\title{
Are Bad Times Good News for the Securities and Ex- change Commission?
}

\author{
Tim Lohse \\ Christian Thomann
}

July, 2014 


\title{
Are Bad Times Good News \\ for the Securities and Exchange Commission?
}

\author{
Tim Lohse ${ }^{1}$ and Christian Thomann ${ }^{2}$
}

June 2014

\begin{abstract}
There exists a considerable debate in the literature investigating how stock market upswings or downswings impact financial market regulation. The present paper contributes to this literature and investigates whether financial market regulation follows a regulative cycle: does regulation, and consequently investor protection, increase as a result of a stock market downturn (as argued by, e.g., Zingales (2009)) or - contrary to the regulative cycle hypothesis - as a result of an upswing (as claimed by Povel (2007), or Hertzberg (2003)) Following Jackson and Roe (2009), we use funding data on the world's most important financial market regulator, the U.S. Securities and Exchange Commission (SEC), as a proxy for the politically desired degree of regulation. We apply time series analysis. Using more than 60 years of data, we show that the SEC's funding follows a regulative cycle: A weak stock market results in increased resources for the SEC. A strong stock market results in reduced resources. Our findings underline the downside of regulation as the regulative cycle amplifies the technical procyclicality inherent in regulation.
\end{abstract}

KEYWORDS: Financial Regulation, Procyclicality, Securities and Exchange Commission, Stock Market.

JeL Classification: G28, G18, C32

\footnotetext{
${ }^{1}$ Berlin School of Economics and Law, Alt-Friedrichsfelde 60, 10315 Berlin, Germany, and Max Planck Institute for Tax Law and Public Finance, Marstallplatz 1, 80539 Munich, Germany. Tim.Lohse@hwr-berlin.de.

${ }^{2}$ Royal Institute of Technology (KTH), Centre of Excellence for Science and Innovation Studies (CESIS), Lindstedtsvägen 30, 10044 Stockholm, Sweden, Center for Risk and Insurance, Leibniz Universität Hannover, Germany, Ministry of Finance, Stockholm, Sweden. phone: + 468790 6000, fax: + 468790 6741, christian.thomann@indek.kth.se (corresponding author).
}

The views expressed in this paper and all remaining errors are solely the responsibility of the authors. 


\section{INTRODUCTION}

The causal relationship between, on the one hand, stock market development and, on the other hand, disclosure regulation is the subject of an important debate to which this paper contributes. A key question is whether a positive market development leads to an increase or a decrease of regulation. Zingales (2009) and a number of other authors claim that the politically desired degree of regulation, and thereby investor protection, follows a cyclical pattern. ${ }^{1}$ They argue that there exists a tendency to increase regulation (leading to better investor protection) as a reaction to a stock market downturn and vice versa - to decrease regulation in a stock market upswing. Does the politically desired degree of financial market regulation change in such a way with stock market performance? Anecdotal evidence, both from the 2008 financial crisis and earlier episodes of financial turmoil, provides support for this thesis. Recently, in reaction to the financial crisis some important steps to regulate financial markets were taken. These regulative efforts include, among others, the Dodd-Frank Wall Street Reform and Consumer Protection Act in the U.S. and the European Union's system of financial supervisors. Even the Sarbanes-Oxley Act was passed in the aftermath of the declining stock markets following the IT boom. However, the question about a regulative cycle is far from being innocuous. The answer may have considerable impact on the incentives for complying with financial market rules. Zingales' (2009) point is contrasted, among others, by Povel et al. (2007) and Hertzberg (2003) who suggest that violations against financial market rules are more prevalent during boom times. ${ }^{2}$ Recently, this is supported by the empirical findings of Wang et al. (2010) and also of Wang and Winton (2012). Thus, assuming that there is a role for government to protect investors, by regulating and enforcing corporate disclosure, one might conclude society should spend more on regulation in booms than in downturns. ${ }^{3}$ Along these lines, Bebchuk and Neeman (2010) suggest that investor protection will be stronger in growing economies because firms which need to raise capital from outside investors are interested in strict

\footnotetext{
${ }^{1}$ Zingales (2009) is not the only paper claiming that there exists such a tendency. Rajan and Zingales (2003), Leuz and Wysocki (2008), Jackson and Roe (2009), Brunnermeier et al. (2009), Benmelech and Moskowitz (2010), Bertomeu and Magee (2011) and Wagenhofer (2011) suggest that regulation follows a cyclical pattern.

${ }^{2}$ Povel et al. (2007) suggest that the incentives for firms to commit fraud are greatest in relatively good times. It is in such times that investors will rely on publicly available information, which a fraudulent firm might manipulate, to detect "bad" firms. Once times are not too good investors have stronger incentives to monitor and firms manipulating their public information are likely to be caught. However, during very good times investors will assume that a firm which, according to public data, does not perform is having a bad day. Thus, there will be no incentive to manipulate during such times.

${ }^{3}$ There exists a substantial literature (e.g. Loebbecke et al. 1989, Beasley 1996; Bell and Carcello 2000) establishing that an individual firm's financial results might impact its probability of fraudulent reporting. The relation between stock-market wide conditions and a firm's probability to commit fraud is, however, unclear.
} 
rules protecting investors. ${ }^{4}$ This interest is particularly important for entrepreneurial firms which are likely to have investments which need to be funded with external capital. $^{5}$

The present paper uses time series analysis to shed light on this debate. We consider the world's most important and most powerful regulator, namely the U.S. Securities and Exchange Commission (SEC). Following Jackson and Roe (2009), we use the SEC's budget to proxy investor protection, i.e. regulation. In light of a recent doubling of the SEC's budget - from $\$ 830$ million in 2007 to $\$ 1.6$ billion in 2010 - we analyze whether the SEC's regulatory funding follows a regulative cycle. For our analysis we collect time series data on stock market returns and the SEC's budget from 1946-2007. ${ }^{6} \mathrm{We}$ estimate vector auto regressions. Our analysis follows Leuz and Wysocki's (2008) suggestion to investigate into the overall dynamics of financial reporting and disclosure regulation. Leuz and Wysocki (2008), and also Bertomeu and Magee (2011), notice that there is a lack of research which looks at market-wide and aggregate economic and social consequences of this regulation since most of the research on disclosure regulation so far is conducted on the firm level. Using data on aggregate funding for one of the central financial market regulators for the United States our paper tries to fill this gap in the literature.

We contribute to the literature by providing formal evidence on the regulative cycle hypothesis: A strong stock market leads politicians to reduce the SEC's budget while a weak market tends to increase the agency's resources. As mentioned above, using the SEC's budget fulfills Leuz' and Wysocki's (2008, p. 17) request to apply broader measures for the intensity of regulation than those which had been analyzed so far. Our findings underline the downside of regulation because a regulative cycle, driven by politicians' actions, amplifies the somewhat technical procyclicality inherent in regulation. Regulation that may itself induce procyclicality includes accounting rules and capital standards (Bernanke 2009). Indeed, the international Basel III agreement states that "[o]ne of the most destabilizing elements of the crisis has been the procyclical amplification of financial shocks throughout the banking system, financial markets and the broader economy" (Bank for International Settlements 2010, p. 5). Applied to bank lending, procyclicality implies that financial institutions loosen credit in boom times and tighten credit in downturns.

The remainder of the paper is organized as follows. First, we briefly report some institutional information regarding the SEC and its funding. Thereafter, we explain our hy-

\footnotetext{
${ }^{4}$ Bebchuk and Neeman's (2010, p. 1110) prediction 4 states: "Investor protection will be higher in growing economies in which the value of the new capital that needs to be raised from outside investors is largely relative to the value of the capital already in the hands of existing public firms."

${ }^{5}$ Brown et al. (2013) study the impact of shareholder protection on (young) firms' spending on research and development. Martinsson (2013) discusses how financial regulation might even impact the demand for skilled labour.

${ }^{6}$ Our results hold if we extend the series to include years including 2010. See section 3.3.
} 
pothesis and subject it to econometric testing. We present our data and the estimation method. The last section concludes.

\section{The Securities and Exchange Commission}

The task of the U.S. Securities and Exchange Commission is, generally speaking, to "protect investors, maintain fair, orderly, and efficient markets, and facilitate capital formation" (SEC 2011). After the Great Crash of 1929, there was a consensus in the U.S. that, for the economy to recover, the public's faith in the capital markets needed to be restored. In response to the Great Depression in the U.S. during the 1930s, the public demanded increased economic regulation. It was for these reasons that Congress passed the Securities Act of 1933 mandating disclosure of information by issuers of securities. The Securities Exchange Act of 1934 created the SEC. Both laws aimed at providing the markets and investors with clear rules of honest dealing and reliable information. ${ }^{7}$

In theory, the SEC requires "companies publicly offering securities for investment dollars ... [to] tell the public the truth about their businesses, the securities they are selling, and the risks involved in investing [, and] people who sell and trade securities - brokers, dealers, and exchanges - ... [to] treat investors fairly and honestly, putting investors' interests first" (SEC 2011). To achieve these goals, the SEC provides detailed information on its websites and through the EDGAR database of disclosure documents, which public companies must file with the Commission. The potential prosecution for violations gives companies an incentive to comply. The enforcement authority allows the SEC to bring civil enforcement actions against individuals or companies found to have violated securities law. Usual infractions are, among others, accounting fraud, insider trading, and providing misleading or false information about securities and the companies that issue them (SEC 2012).

The SEC, being a federal agency, receives its budget from the federal government. Nevertheless, it also generates its own revenue. This revenue stems from fees, securities registrations and tender offers, etc. However, the SEC can only spend the amount agreed upon by the federal government. Since 1982, these revenues have always exceeded the SEC's budget and the SEC has thus positively contributed to the federal budget. ${ }^{8}$ The question about how effective such public - rather than private - enforcement of securities laws is, has been intensively discussed by the literature. Jackson (2013) provides an overview of this literature. ${ }^{9}$ La Porta et al. (2006) or Kim (2008)

\footnotetext{
${ }^{7}$ Seligman (2003) provides a comprehensive review of the SEC's history.

${ }^{8}$ SEC (2001) states that during the fiscal year of 2001 it collected $\$ 2.06$ bn in fees. $48 \%$ of that sum was generated from securities registrations; $50 \%$ came from securities transactions. The remaining $2 \%$ were from tender offer, merger, and other items. The agency’s 2001 budget was $\$ 430$ million.

${ }^{9}$ Class action litigation as a rather important means of private enforcement is discussed in detail, e.g. by Ulen (2011). The more sophisticated question whether or not a "one size fits all" regulation should be uniformly applied to all equity trading platforms within a country is analyzed by Boyle and Meade
} 
advocate private enforcement. Jackson and Roe (2009) but also Lohse, Pascalau and Thomann (2014) suggest that there is a role for public enforcement. Therefore, in the sense of Dewatripont and Tirole (1999) and Shleifer (2005), one can consider the SEC to be an advocate, first, in the interest of the well-behaving financial market participants, and, second, for the cause of comparatively disorganized groups of investors. Given the crucial role that access to capital plays for entrepreneurs and dynamic firms this group of investors is of particular importance as it may provide an additional source of capital besides standard financial intermediaries. Consequently, the government's decision about the SEC's budget is likely to have real economic effects for expansive firms.

\section{EMPIRICAL ANALYSIS}

\subsection{DATA AND ECONOMETRIC MODEL}

We will analyze the following hypothesis:

Regulative cycle hypothesis: Positive (negative) returns on the financial markets will decrease (increase) the intensity of SEC regulation.

To test our hypothesis we collect data on the SEC's budget from the SEC's annual reports. ${ }^{10}$ Since World War II led to a very strong focus on defence spending we only use data from 1945 to $2007 .{ }^{11}$ Following Jackson and Roe (2009), we measure spending on financial market regulation using both (a) the simple inflation-adjusted budget of the SEC and (b) the ratio of the SEC's inflation-adjusted budget to the number of stocks traded in the New York Stock Exchange (NYSE). ${ }^{12}$ Using the number of stocks traded on the NYSE to normalize the spending on the SEC follows from the institutional settings: many foreign companies choose to cross-list their stocks on this exchange. By cross-listing their stocks on the NYSE, companies are able to signal their compliance with the disclosure standards demanded by the NYSE and the SEC. This is also referred to as the bonding hypothesis. We refer to the logged series as (a) sec_budget and (b)

(2008). In respect to the SEC as a public enforcement institution, a recent study by Lohse, Pascalau and Thomann (2014) shows that increases in the SEC's resources improve compliance with financial market rules. Even Del Guerico et al. (2013) show that there is a deterrence effect associated with SEC enforcement.

${ }^{10}$ The data is on fiscal year basis. Since 1976 the federal fiscal year ends in October. Prior to that, the fiscal year ended in June.

${ }^{11}$ In order to avoid our results being driven by the financial crisis or the Madoff scandal, we consider only data up to 2007. We provide a robustness check for the time until 2010 in section 3.2. The number of observations we use is comparable to Jackson and Roe (2009) who use, at most, 55 observations. Furthermore, the normalization procedure used in Jackson and Roe (2009) is comparable to the one employed in this paper.

12 Data on the number of stocks traded on the NYSE is obtained from NYSE (2009). We use the Bureau of Labor Statistic's consumer price index (Bureau of Labor Statistics, 2009) to inflate the SEC's budget to 2007 dollars. It should be remarked that the results of our empirical analysis can also be derived independently of this normalization. We discuss this is issue in section 3.2. 
sec_stocks, respectively. ${ }^{13}$ Thus, our measures for the intensity of financial market regulation in period $t$ are $s e c \_b u d g e t_{\mathrm{t}}$ and $s e c \_s t o c k s_{t}$, respectively.

We proxy stock market gains or losses using annual stock market return data from the Center of Research in Security Prices (CRSP). More precisely, we use the valueweighted returns with dividends index. ${ }^{14}$ Again, we adjust for inflation using the consumer price index. This gives us the series return. Figure 1 presents the three series used in the investigation. The data encompasses the time period from 1945 to 2007.

Fig. 1: Development of return, and the SEC's budget and the SEC's normalized budget 1945-2007

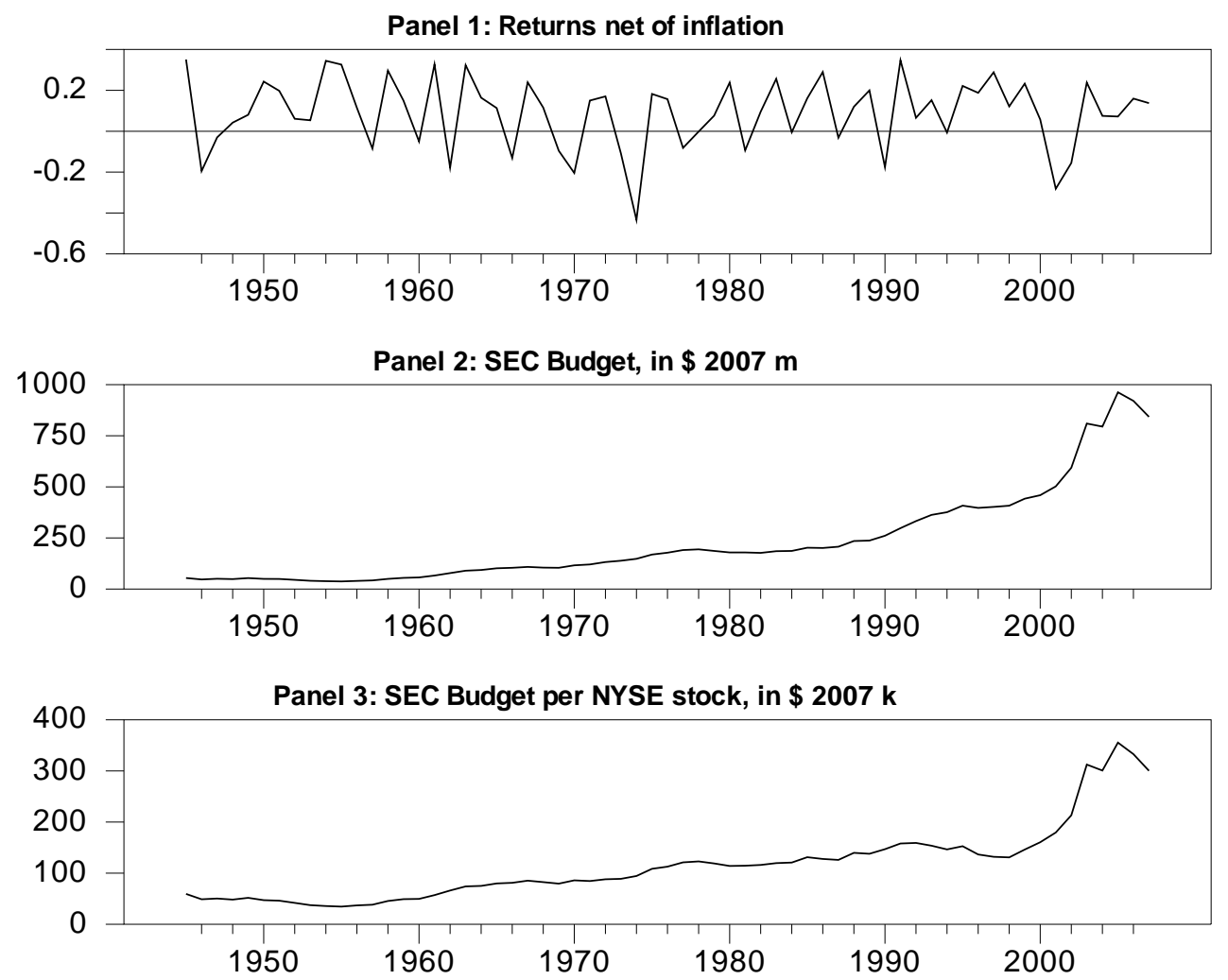

Panel 1 marks the inflation adjusted return on the value weighted return with dividends index in $t\left(\right.$ return $\left._{t}\right)$. The return data is from CRSP. Panel 2 shows the inflation-adjusted budget of the SEC [in 2007 dollars]. Panel 3 marks the ratio of the SEC's budget [in 2007 dollars] to the number of stocks listed on the NYSE in period $t$. Examining the stationarity of the series, we find that the augmented Dickey-Fuller Unit Root tests

\footnotetext{
${ }^{13}$ The intuition behind this normalization is that two firms with each $\$ 1$ bn market capital are likely to create more work for the SEC than a single firm with a market capitalization of $\$ 2 \mathrm{bn}$.

${ }^{14}$ We also try other indices, e.g. the SP 500. Yet, the results are not materially affected by the choice of the index.
} 
indicate that the return series is stationary. The same tests also indicate that sec_stocks, one of our two measures of regulatory intensity, is trend stationary. The Dickey-Fuller test statistic including a deterministic time trend and two autoregressive lags for the sec_stocks series is -4.03 . The appropriate $5 \%$ critical value $\left(\mathrm{H}_{0}\right.$ : series contains unit root) is equal to -3.48 . Considering our interest in the marginal effects, we choose to simply eliminate the deterministic time trend following Enders (2004). Checking the $t$ statistics and considering the Schwartz Bayesian Criterion $(\mathrm{SBC})^{15}$ - both are presented in table 1 - we find that the deterministic trend is best modelled as a first degree polynomial. We regress sec on this polynomial and refer to the detrended series as sec_stocks*. ${ }^{16}$

For sec_budget, our second measure of regulatory intensity, which in accordance with Jackson and Roe (2009) measures the SEC's inflation adjusted budget. Using the augmented Dickey-Fuller we cannot reject the hypothesis of a unit root at the $1 \%$-level. ${ }^{17}$ Given that we want to ensure that our results are neither driven by our normalization procedure nor the detrending, we decide to difference this series and proceed with dsec_budget.

We test our hypothesis using VAR models. By estimating bivariate VARs we are able to capture the interaction between our measures for the SEC's budget and the return series. As both return and the two measures for the SEC's budget, sec_stocks* and $d s e c \_b u d g e t$, are stationary we formulate the following primitive system:

$$
\begin{gathered}
\sec _{t}=\gamma_{1}+\sum_{i=1}^{n} \alpha_{1 i} \sec _{t-i}+\sum_{i=1}^{n} \beta_{1 i} \text { return }_{t-i}+\varepsilon_{1 t} \\
\text { return }_{t}=\gamma_{2}+\sum_{i=1}^{n} \alpha_{2 i} \sec _{t-i}+\sum_{i=1}^{n} \beta_{2 i} \text { return }_{t-i}+\varepsilon_{2 t}
\end{gathered}
$$

$s e c$ is a placeholder for sec_stocks $*$ and dsec_budget and $\gamma_{1}$ and $\gamma_{2}$ are constants. $\varepsilon_{1 \mathrm{t}}\left(\varepsilon_{2 \mathrm{t}}\right)$ are the shocks to each individual series. The coefficients $\beta_{1 i}$ and $\alpha_{2 i}$ capture the interrelation between the two series. It is the coefficients $\beta_{1 i}$, and also the impulse response functions, which serve as a direct test of the regulative cycle hypothesis. The coefficients $\beta_{1 i}$ test if past positive values of return decrease $\sec _{t}$. Further, if for sec (return) there is a tendency of regulatory intensity in the preceding periods to influence the regulatory intensity (return) in the present period, then the autocorrelation coefficients $\alpha_{1 \mathrm{i}}\left(\beta_{2 \mathrm{i}}\right)$ should be significant. The coefficients $\alpha_{2 \mathrm{i}}$ allow testing if increases in the SEC's budget impact returns.

\footnotetext{
15 The univariate $\mathrm{SBC}$ are calculated as $S B C=T \log$ (sum of squared residuals) $+n \log (T)$ where $n$ is the number of parameters estimated and $T$ is the number of usable observations.

${ }^{16}$ Dickey-Fuller-tests indicate that $s e c \_s t o c k s *$ is stationary. The finding that sec_stocks has a unit root can be explained by a number of factors. First, a rising complexity of the firms supervised and, second, a growth of the average market capitalization of the firms traded on the NYSE.

17 The results are very similar if we detrend sec_budget using a second degree polynomial. Lohse, Pascalau and Thomann (2014) use this approach.
} 
Since $\sec _{t}\left(\right.$ return $\left._{t}\right)$ is correlated with the error term $\varepsilon_{1 \mathrm{t}}\left(\varepsilon_{2 \mathrm{t}}\right)$ the model presented in (1) and (2) is unidentified. We consequently need to restrict the primitive system. Applying the commonly used Choleski decomposition, we assume that contemporaneous innovations in $\sec _{t}, \varepsilon_{1 \mathrm{t}}$, do not affect the contemporaneous value of return ${ }_{t}$. To fit the model we then follow Enders (2004) and consider, among others, the multivariate SBC. ${ }^{18}$

The estimation of the bivariate VAR models allows for a number of insights into the interrelation between the series. Granger causality tests analyze if past values of one series determine the present value of another series. Technically, testing whether, e.g., returns Granger causes sec is done by using an F-test to test the restriction:

$$
\beta_{11}=\beta_{12}=\ldots=\beta_{\text {ln }}=0 .
$$

Innovation accounting, namely impulse response analysis and variance decomposition, examines the interaction between the variables. The impulse responses which build upon the moving average representation of (1) and (2) can show how, e.g., sec responds to a shock in return $(\mathrm{sec})$. Confidence bands for the impulse response functions allow them to serve as a formal test for our hypothesis. ${ }^{19}$ The forecast error variance decomposition quantifies the proportion of the movements of a series resulting from its own shocks and from the shocks attributable to the other series.

\subsection{ECONOMETRIC RESULTS}

Using standard model selection criteria we find that a VAR with a constant and one lag provides for the best fit for the VAR between sec_stocks* and return. Table 1 reports the model selection tests and the diagnostic checks of the VAR model. ${ }^{20}$

Since the variables exhibit only a very low degree of contemporaneous correlation $\left(\tau\left(\varepsilon_{1}, \varepsilon_{2 t}\right)=-0.08\right)$ the ordering of the Choleski decomposition is uncritical. The estimated VAR model is (standard errors in parentheses):

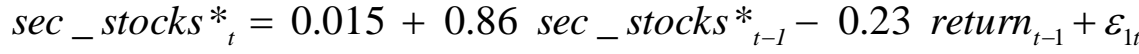

$$
\begin{aligned}
& \text { (0.011) (0.05) } \\
& \text { return }_{t}=0.10-0.07 \text { sec }_{\text {stocks }}{ }_{t-1}-0.09 \text { return }{ }_{t-1}+\varepsilon_{2 t}
\end{aligned}
$$

$$
\text { (0.02) (0.11) (0.13) }
$$

The estimation results indicate a strong support for the regulative cycle hypothesis. First, there exists significant evidence that there is a strong interaction between the two series. We find that return Granger-causes sec_stocks* (at the 1\%-level). The

\footnotetext{
18 The multivariate SBC are calculated as $S B C=T * \log |\Omega|+k * \log T$ where $T$ is the number of usable observations; $|\Omega|$ is the determinant of the variance/covariance matrix of the residuals; and $k$ is the number of parameters estimated.

${ }^{19}$ In this paper we follow the suggestion of Sims and Zha (1999) and obtain confidence bands by Monte Carlo integration.

${ }^{20} \mathrm{ARCH}$ stands for autoregressive conditional heteroskedasticity.
} 
knowledge of the return series consequently provides information about future values of sec_stocks*. Second, the negative coefficient of $\beta_{11}(=-0.23)$ in equation (3) which has a $t$-statistic of -3.83 , indicates that, at the margin, positive returns decrease future spending on the SEC. These two findings together imply that regulation follows a cycle with regulation decreasing as a result of a stock market upswing.

Table 1: Specification Tests and Diagnostic Checks: returns and sec_stocks

\begin{tabular}{|c|c|c|}
\hline Augmented Dickey-Fuller Unit Root Tests & Test Statistics & $1 \%$ crit. Val \\
\hline sec_stocks with 2 lags, nonzero mean & -0.93 & -3.53 \\
\hline sec_stocks with 2 lags, nonzero mean, det. trend & -4.03 (at $5 \%$ level) & -4.11 \\
\hline return 0 lags, non-zero mean & -8.85 & -3.53 \\
\hline Fitting of Trend & Test Statistics & \\
\hline T-Statistic $\mathrm{t}^{1}$ & 22.55 & $\mathrm{SBC}=61.60$ \\
\hline T-Statistic $\mathrm{t}^{2}$ & 1.29 & $\mathrm{SBC}=64.02$ \\
\hline Dickey-Fuller Unit Root Test detrended series & Test statistic & $1 \%$ crit. Val \\
\hline sec_stocks* with 2 lags, nonzero mean & -3.86 & -3.54 \\
\hline \multicolumn{3}{|l|}{ Model Selection (VAR model, 1945-2007) } \\
\hline N of lags: 1 & $\mathrm{SBC}=-526.64$ & \\
\hline$N$ of lags: 2 & $\mathrm{SBC}=-522.29$ & \\
\hline \multicolumn{3}{|l|}{ VAR (final model) } \\
\hline Correlation $\varepsilon_{1 t}, \varepsilon_{2 t}$ & -0.08 & \\
\hline \multicolumn{3}{|l|}{ Granger Causality Tests } \\
\hline sec_stocks* Granger-causes return & $\mathrm{F}=0.47(\mathrm{P}-$ Value $=0.47)$ & \\
\hline return Granger-causes return & $\mathrm{F}=0.53(\mathrm{P}-$ Value $=0.49)$ & \\
\hline sec_stocks* Granger-causes sec_stocks* & $\mathrm{F}=328.72(\mathrm{P}-$ Value $=0.01)$ & \\
\hline return Granger-causes sec_stocks* & $\mathrm{F}=16.54(\mathrm{P}-$ Value $=0.01)$ & \\
\hline \multicolumn{3}{|l|}{ Ljung-Box Q Statistics of residuals } \\
\hline Equation (3) (sec_stocks*) & $\mathrm{P}\left(\mathrm{X}^{2}(4)>16.68\right)=0.01$ & \\
\hline Equation (4) (return) & $\mathrm{P}\left(\mathrm{X}^{2}(4)>6.30\right)=0.18$ & \\
\hline \multicolumn{3}{|l|}{ Lagrange Multiplier Test $\left(\mathrm{H}_{0}\right.$ : no ARCH) } \\
\hline Equation (3) (sec_stocks $\left.{ }^{*}\right)$ & $\mathrm{P}\left(\mathrm{X}^{2}(4)>0.81\right)=0.52$ & \\
\hline Equation (4) $\left(\right.$ return $\left._{t}\right)$ & $\mathrm{P}\left(\mathrm{X}^{2}(4)>0.92\right)=0.49$ & \\
\hline \multicolumn{3}{|l|}{ Innovation Accounting Forecast Error Variance } \\
\hline $\begin{array}{l}\text { return accounted for by sec_stocks* } \\
\text { sec stocks* accounted for by return }\end{array}$ & $\begin{aligned} \mu(0,10) & =0.25 \% \\
& =10 \\
0 & =1952\end{aligned}$ & $\mu(11,20)=0.34 \%$ \\
\hline
\end{tabular}

Innovation accounting provides for additional insights. The forecast error variance decomposition underscores that return has a strong effect on sec_stocks*. Indeed, $20.02 \%$ $(24.06 \%)$ of the forecast error variance of sec_stocks $*$ in the periods 1 through 10 (11 through 20) is attributed to variation in return.

The impulse responses as shown in figure 2 further support the hypothesis. The impulse responses show how a one standard deviation shock to one series (denoted as "shock to") impacts another series or the series itself (denoted as "response of") over time (here: 20 periods). Most importantly, the impulse responses give an insight on the direction of such shocks. The upper-left panel in figure 2 shows the reaction of return to a one standard deviation shock to itself. The lower-left panel shows the reaction of sec_stocks* to return. The upper-right panel shows the reaction of return to a one 
standard deviation shock to sec_stocks*. The confidence bands, drawn as dashed lines, show the $16 \%$ and $84 \%$ fractiles of the posterior bands obtained by Monte Carlo integration. ${ }^{21}$ In figure 2, lower-left panel, we show that a positive 1 standard deviation shock to return (equal to an increase in return by $17.08 \%$ ) has a negative effect on future values of sec_stocks*. The confidence bands indicate the significance of the results. Aggregating over 20 periods, we find that a positive one standard deviation shock to return decreases sec_stocks* by 0.325 . Considering that sec_stocks 2006 is equal to 12.71 this means that such a shock to return reduces the SEC-spending per stock by $2.5 \%$.

Fig 2: Impulse response functions: return and sec_stocks*

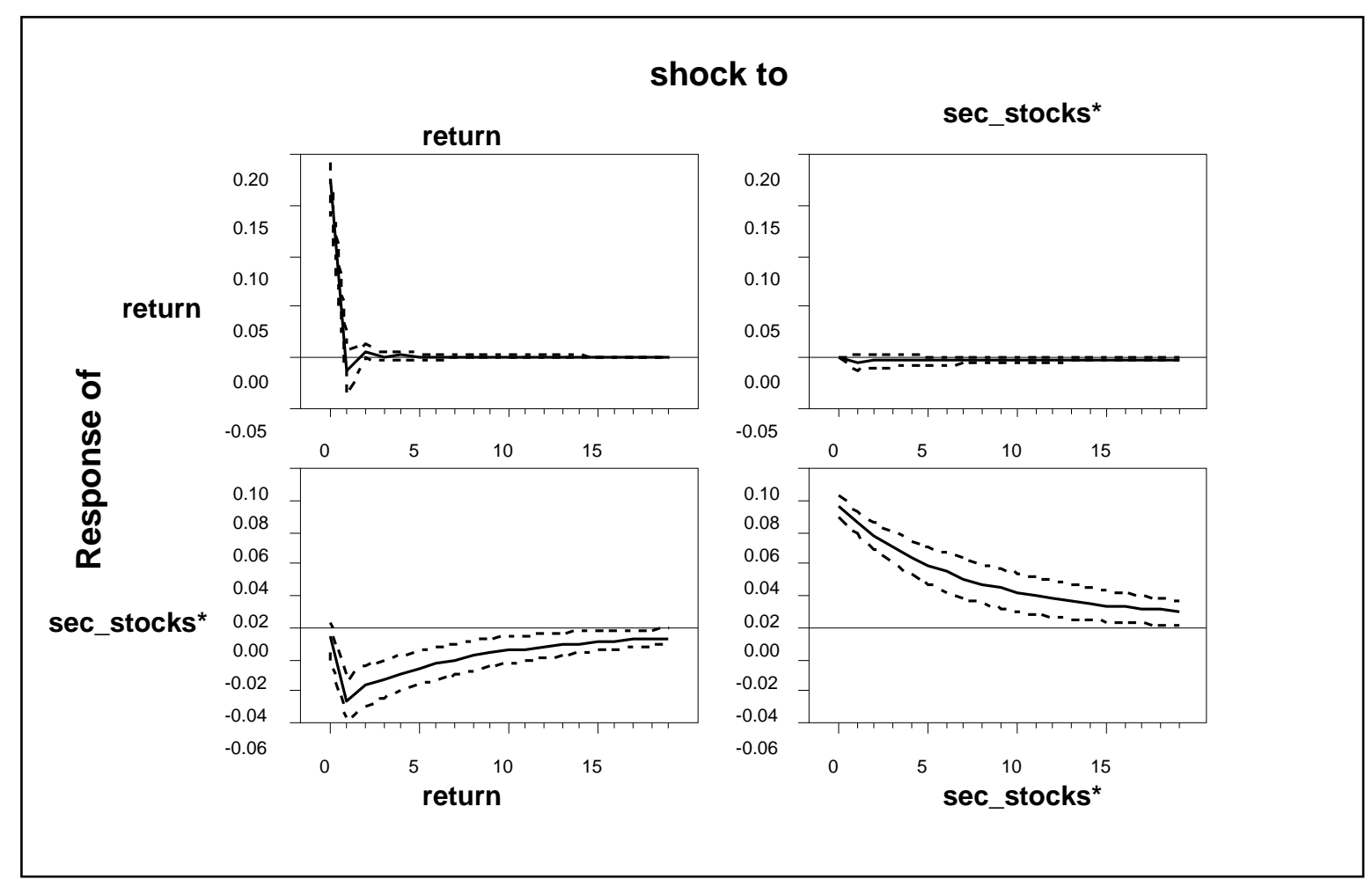

Next, we test the robustness of our results by estimating a bivariate VAR between return and dsec_budget. We thus test if our results are withheld when we do not divide the SEC's budget by the number of stocks traded on the NYSE. In addition, we can test whether our results are affected by detrending the measure of financial market regulation. Again, the SBC indicate that the VAR is best modelled using one lag. Table 2 shows the model selection statistics. The estimated VAR is (standard errors in parentheses):

21 These fractiles correspond to one standard deviation. The econometrics package RATS provides a procedure for estimating error bands according to Sims and Zha (1999). 


$$
\begin{aligned}
& d_{s e c}{ }_{\text {budget }}=0.05+0.29 \mathrm{dsec}_{t} \text { budget }_{t-1}-0.18 \text { return }_{t-1}+\varepsilon_{1 t} \\
& \text { (0.01) (0.11) (0.05) } \\
& \text { return }_{t}=0.09-0.03 \text { dsec }_{-} \text {budget }_{t-1}-0.09 \text { return }_{t-1}+\varepsilon_{2 t}
\end{aligned}
$$

$$
\text { (0.03) (0.27) (0.13) }
$$

Again, the estimation results indicate strong support for our hypothesis. return Grangercauses dsec_budget at the $1 \%$ level. The coefficient of $\beta_{11}$ in equation (5) is negative ( $\left.\beta_{11}=-0.18\right)$ and significant $(t$-statistic $=-3.50)$. The estimated system thus indicates

\begin{tabular}{|c|c|c|}
\hline Augmented Dickey-Fuller Unit Root Tests & Test Statistics & $1 \%(5 \%)$ crit. Val \\
\hline sec_budget with two lags, nonzero mean & -0.39 & -3.53 \\
\hline sec_budget with two lags, nonzero mean, trend & -3.20 & $-3.48(-3.20)$ \\
\hline dsec_budget with one lag, nonzero mean & -3.39 & $-3.53(-2.90)$ \\
\hline \multicolumn{3}{|l|}{ Model Selection (VAR model, 1945-2007) } \\
\hline N of lags: 1 & \multicolumn{2}{|l|}{$\mathrm{SBC}=-535.92$} \\
\hline$N$ of lags: 2 & \multicolumn{2}{|l|}{$\mathrm{SBC}=-531.13$} \\
\hline \multicolumn{3}{|l|}{ VAR (final model) } \\
\hline $\begin{array}{l}\text { correlation } \varepsilon_{1 t}, \varepsilon_{2 t} \\
\text { Granger Causality Tests }\end{array}$ & \multicolumn{2}{|l|}{-0.036} \\
\hline dsec_budget Granger-causes return & \multicolumn{2}{|c|}{$\mathrm{F}=0.02(\mathrm{P}-$ Value $=0.90)$} \\
\hline returns Granger-causes return & \multicolumn{2}{|c|}{$\mathrm{F}=0.45(\mathrm{P}-$ Value $=0.50)$} \\
\hline dsec_budget Granger-causes dsec_budget & \multirow{2}{*}{\multicolumn{2}{|c|}{$\mathrm{F}=6.05(\mathrm{P}-$ Value $=0.02)$}} \\
\hline returns Granger-causes dsec_budget & & $\mathrm{F}=12.26(\mathrm{P}-$ Value $=0.01)$ \\
\hline \multicolumn{3}{|l|}{ Ljung-Box Q Statistics } \\
\hline equation 1 (dsec_budget) & \multirow{2}{*}{\multicolumn{2}{|c|}{$\begin{array}{l}\mathrm{P}\left(\mathrm{X}^{2}(4)>11.44\right)=0.02 \\
\mathrm{P}\left(\mathrm{X}^{2}(4)>9.62\right)=0.05\end{array}$}} \\
\hline equation 2 (return) & & \\
\hline \multicolumn{3}{|l|}{ Innovation Accounting Forecast Error Variance } \\
\hline $\begin{array}{l}\text { return accounted for by dsec_budget } \\
d s e c \text { budget accounted for by return }\end{array}$ & \multicolumn{2}{|c|}{$\begin{array}{l}\mu(0,20)=0.01 \% \\
\mu(0,20)=\mu(0,10)=16.1 \%\end{array}$} \\
\hline
\end{tabular}
that positive values of return have a negative impact on the $d s e c \_b u d g e t$ series. Table 2 shows the specification tests.

Table 2: Specification tests and diagnostic checks: return and $d s e c \_b u d g e t$

The respective impulse response functions are presented in figure 3. the lower left panel, e.g., shows the reaction of $d \_s e c \_b u d g e t$ to a 1 standard deviation shock to return. The panel reveals that this shock to return has a negative and significant effect on dsec_budget. This underscores that our results are not driven by the detrending of our first measure of regulatory intensity. 
Fig 3: Impulse responses return and dsec_budget

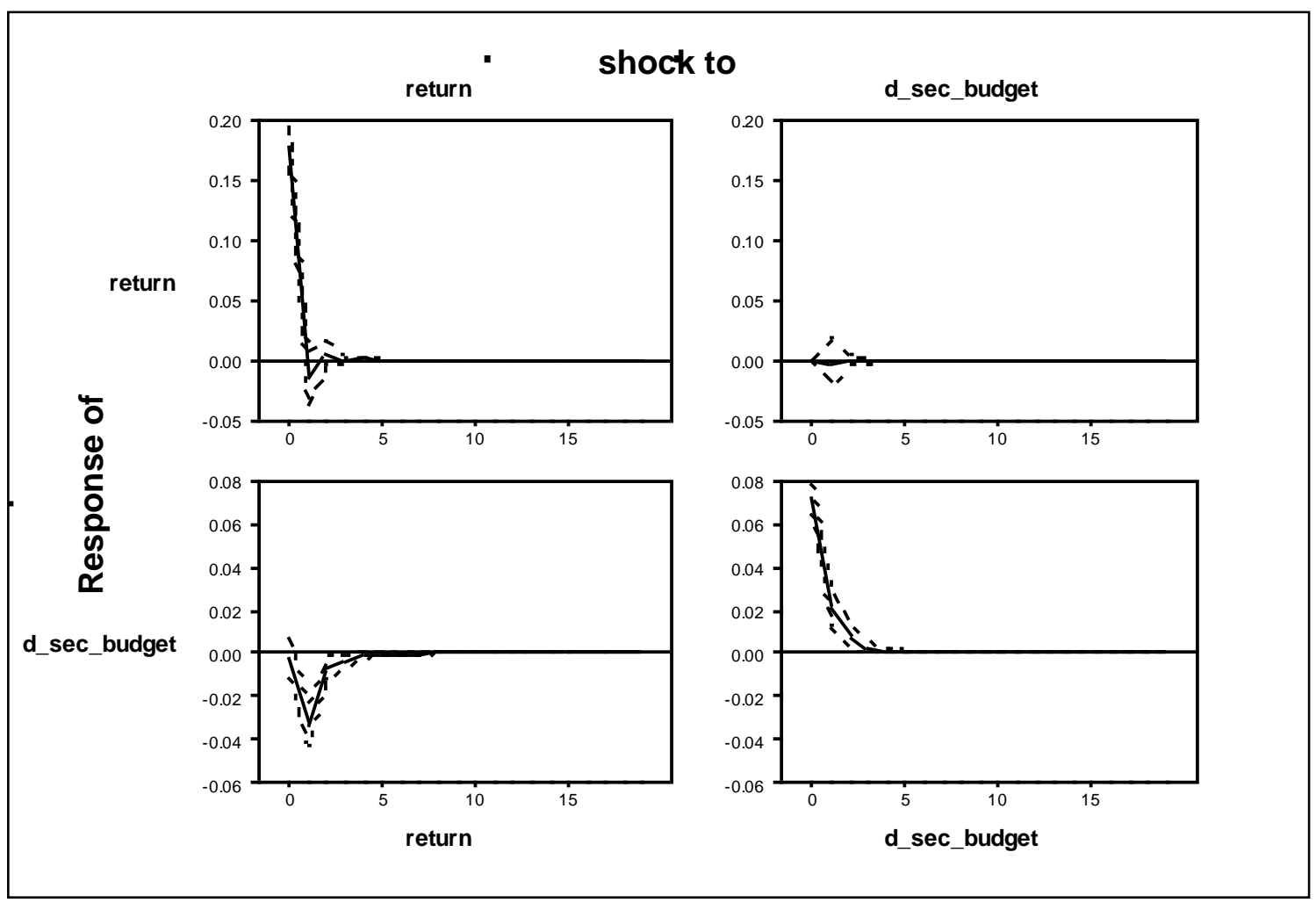

\subsection{ROBUSTNESS}

To complement our empirical analysis and to test the robustness of the results we estimate a number of alternative VAR models. First, we estimate two alternative models looking at the time period up to 2007. (A) We model the intensity of financial market regulation by the quotient of the SEC's budget and the market capitalization of the return series. $^{22}$ (B) We use the returns on the Standard and Poor's 500 index net of inflation. Second, we re-estimate the two models presented in this paper for the time period up to 2010. Again, the results do not change. For each of the four models we estimate to check the robustness of our results, we find that significant coefficient estimates, Granger causality tests and impulse responses support the regulative cycle hypothesis. ${ }^{23}$ Thus, each of these alternative formulations provides additional support for our regulative cycle hypothesis.

\footnotetext{
22 This data is from CRSP.

${ }^{23}$ These results are available from the authors upon request.
} 


\section{CONCLUSION}

Institutions of financial regulation can be considered as advocates, first, in the interest of the compliant market participants, and, second, for the cause of comparatively disorganized groups of investors. These groups of investors are of particular importance for entrepreneurs and fast-growing companies because they might provide firms with an additional source of capital. Consequently, the government's decision about the regulator's budget is likely to have real economic effects for entrepreneurial firms. A lower level of financial market regulation may lead to increases in firms' cost of external capital. Given that entrepreneurs may need to access financial markets both in upturns and downswings it is of importance understanding how the intensity of regulation is impacted by stock market movements. The present paper sheds light on this important issue and investigates whether regulation increases as a result of a stock market upswing or of a downturn. A possible answer to this question is essentially the regulative cycle hypothesis claiming that politicians increase regulation in bad times and decrease regulation in boom times. We test this hypothesis using time series analysis. Following Jackson and Roe (2009), we use data on the U.S. Securities and Exchange Commission's funding to proxy regulation. We proxy stock market returns using the returns on a broad market index. We contribute to the literature by providing formal evidence of a regulative cycle. We find that a strong stock market performance, at the margin, reduces the SEC's budget. We find that these marginal effects are very robust to different measures of SEC funding. Positive stock market returns have a negative effect on the SEC's inflation adjusted budget. This effect can also be found when looking at different normalized measures of the budget of the SEC.

The verification of a regulative cycle for the SEC's budget is in line with Jackson and Roe (2009), Brunnermeier et al. (2009), Benmelech and Moskowitz (2010), Rajan and Zingales (2003) and Leuz and Wysocki (2008). But our findings are somewhat in contrast to Bebchuk and Neeman's (2010) theoretical argument that it is high economic growth (rather than poor economic development) or a developed stock market that leads to a high level of investor protection. Our findings suggest that politicians' actions amplify the detrimental procyclicality inherent in regulation. Acknowledging that static capital requirements might result in procyclicality, the new Basel III rules for banks incorporate some countercyclical buffers. Furthermore, macroprudential regulation, e.g. the new European Systemic Risk Board and the Financial Stability Oversight Council in the U.S., aims at reducing systemic risks during their build-up in boom times. Given that macroprudential regulators will be needed most during boom times it is important that their budgets do not follow the regulative cycle. 


\section{ACKNOWLEDGMENTS}

The authors thank two anonymous referees, Johan Eklund, Martin Eling, Razvan Pascalau, Lars Petterson, Daniel Wiberg, participants of the workshop on Regulation, Entrepreneurship and Firm Dynamics in Stockholm, the German Finance Association meeting and seminar participants at Humboldt University Berlin, the Universities of Hannover, Potsdam, and Ulm and the Social Science Research Center Berlin (WZB) for valuable comments on earlier versions of the paper. Tim Linderkamp provided very valuable research assistance. All errors and omissions are our own.

\section{REFERENCES}

Beasley, M. S. (1996). An Empirical Analysis of the Relation between the Board of Director Composition and Financial Statement Fraud. Accounting Review, 71(4), 443465 .

Bebchuk, L. A., \& Neeman, Z. (2010). Investor Protection and Interest Group Politics. Review of Financial Studies, 23(3), 1089-1119.

Bell, T. B., \& Carcello, J. V. (2000). A Decision Aid for Assessing the Likelihood of Fraudulent Financial Reporting. Auditing: A Journal of Practice \& Theory, 19(1), 167182.

Benmelech, E., \& Moskowitz, T. J. (2010). The Political Economy of Financial Regulation: Evidence from U.S. State Usury Laws in the 19th Century. Journal of Finance, 65(3), 1029-1073.

Bernanke, B. S. (2009). The Financial Crisis and Community Banking, March 20, 2009, http://www.federalreserve.gov/newsevents/speech/bernanke20090320a.htm. Accessed 30 August 2013.

Bertomeu, J. \& Magee, R. P. (2011). From low-quality reporting to financial crises: Politics of disclosure regulation along the economic cycle. Journal of Accounting and Economics, 52(2), 209-227.

Boyle, G., \& Meade, R. (2008). Intra-country regulation of share markets: does one size fit all? European Journal of Law and Economics, 25(2), 151-165.

Bank for International Settlements (2010). Basel Committee on Banking Supervision: Basel III: A global regulatory framework for more resilient banks and banking systems. Basel.

Brunnermeier, M., Crockett, A., Goodhart, C., Persaud, A. D. \& Shin, H. (2009). The Fundamental Principles of Financial Regulation. Geneva Reports on the World Economy, 11, 16-48.

Bureau of Labour Statistics (2009). Consumer Price Index. ftp://ftp.bls.gov./pub/special.requests/cpi/cpai.txt. Accessed 30 August 2013. 
Brown, J. R., Martinsson, G., \& Petersen, B. C. (2013). Law, stock markets, and innovation. The Journal of Finance, 68(4), 1517-1549.

Del Guercio, D., Odders-White, E., \& Ready, M. (2013). The Deterrence Effect of SEC Enforcement Intensity on Illegal Insider Trading. Available at SSRN 1784528.

Dewatripont, M., \& Tirole, J. (1999). Advocates. Journal of Political Economy, 107(1), $1-39$.

Enders, W. (2004). Applied Econometric Time Series. $2^{\text {nd }}$ edition. Holboken: Wiley.

Hertzberg, A. (2003). Managerial Incentives, Misreporting, and the Timing of Social Learning: A Theory of Slow Booms and Rapid Recessions. Working paper, Northwestern University.

Jackson, H. E. (2013). Public Enforcement: An Update of Literature on Resource-Based Evidence. Unpublished Manuscript.

Jackson, H. E., \& Roe, M. J. (2009). Public Enforcement of Securities Laws: ResourceBased Evidence. Journal of Financial Economics, 93(2), 207-238.

Kim, I. (2008). Securities laws 'facilitating' private enforcement. European Journal of Law and Economics, 25(1), 17-38.

La Porta, R., Lopez-de-Silanes, F., \& Shleifer, A. (2006). What works in securities laws? Journal of Finance, 61(1), 1-32.

Leuz, C., \& Wysocki, P. (2008). Economic Consequences of Financial Reporting and Disclosure Regulation: A Review and Suggestions for Future Research. MIT Sloan School of Management Working Paper.

Loebbecke, J. K., Eining, M. M., \& Willingham, J. J. (1989). Auditors' experience with material irregularities: Frequency, nature, and detectability. Auditing: A Journal of Practice \& Theory, 9(1), 1-28.

Lohse, T., Pascalau, R., \& Thomann, C. (2014). Public Enforcement of Securities Market Rules: Resource-based evidence from the Securities Exchange Commission, Journal of Economic Behavior and Organization (forthcoming), http://dx.doi.org/10.1016/j.jebo.2014.06.010.

Martinsson, G. (2013). Financial Reform, Demand for Skilled Labor, and Growth. Swedish House of Finance Research Paper No. 13-04.

NYSE (2009). Facts and Figures, NYSE Historical Statistics, http://www.nyxdata.com/nysedata/NYSE/FactsFigures/tabid/115/Default.aspx. Accessed 30 August 2013.

Povel, P., Singh, R., \& Winton, A. (2007). Boom, Busts, and Fraud. Review of Financial Studies, 20(4), 1219-1254.

Rajan, R. R., \& Zingales, L. (2003). Saving Capitalism from the Capitalists. New York: Random House. 
SEC (2001). Securities and Exchange Commission Annual Reports, www.sec.gov. Accessed 30 August 2013.

SEC (2011). Securities and Exchange Commission Annual Reports, www.sec.gov. Accessed 30 August 2013.

SEC (2012). Securities and Exchange Commission Annual Reports, www.sec.gov. Accessed 30 August 2013.

Seligman, J. (2003). The Transformation of Wall Street. $3^{\text {rd }}$ edition. New York: Aspen.

Shleifer, A. (2005). Understanding Regulation. European Financial Management, $11(4), 439-451$.

Sims, C. A., \& Zha, T. (1999). Error Bands for Impulse Responses. Econometrica, 67(5), 1113-1156.

Ulen, T. S. (2011). An introduction to the law and economics of class action litigation. European Journal of Law and Economics, 32(2), 185-203.

Wagenhofer, A. (2011). Towards a theory of accounting regulation: A discussion of the politics of disclosure regulation along the economic cycle. Journal of Accounting and Economics, 52(2), 228-234.

Wang, T., Winton, A., \& Yu, X. (2010). Corporate Fraud and Business Conditions: Evidence From IPOs. Journal of Finance, 65(6), 2255-2292.

Wang, T., \& Winton, A. (2012). Competition and Corporate Fraud Waves. Unpublished Manuscript.

Zingales, L. (2009). The Future of Securities Regulation. Journal of Accounting Research, 47(2), 391-425. 